\title{
Success in science: what we can learn from women artists
}

\author{
Lona Mody, ${ }^{1,2}$ Joel D. Howell, ${ }^{3,4}$ and Sanjay Saint ${ }^{5,6}$ \\ 'Department of Internal Medicine, Division of Geriatric and Palliative Medicine, University of Michigan Medical School, Ann Arbor, Michigan, USA. ${ }^{2}$ Ceriatrics Research Education and Clinical Center, Veterans \\ Affairs Ann Arbor Healthcare System, Ann Arbor, Michigan, USA. ${ }^{3}$ Director, Medical Arts Program, University of Michigan, Ann Arbor, Michigan, USA. ${ }^{4}$ Departments of History, Internal Medicine, and Health
} Management \& Policy, University of Michigan, Ann Arbor, Michigan, USA. ${ }^{5}$ Patient Safety Enhancement Program and Center for Clinical Management Research, Veterans Affairs Ann Arbor Healthcare System, Ann Arbor, Michigan, USA. ${ }^{6}$ Division of Hospital Medicine, Department of Medicine, University of Michigan Health System, Ann Arbor, Michigan, USA.

The practice of medicine is an art, not a trade; a calling, not a business; a calling in which your heart will be exercised equally with your head. - William Osler (1)

Good artists - like good scientists - strive to innovate, to create, to differentiate themselves from both conventional wisdom and the guidance of their teachers. They struggle to create something new and valuable. Both artists and scientists produce their work within a specific social and political context. Because a key part of that context is gender, the male-dominated nature of Western culture has long meant that women have faced additional gender-based challenges.

Over the years, women artists have confronted adversity in the midst of highly traditionalist - and even oppressive - institutions. Many succeeded and now serve as inspirational role models. While most scientists cannot paint like Georgia O'Keeffe, or sculpt like Camille Claudel, we have much to learn from artists' lived experiences. In this Viewpoint, we consider what we as scientists can learn from three female artists.

\section{Elisabeth Vigée Le Brun \\ (France, 1755-1842): Know when to change course}

Elisabeth Vigée La Brun was born in Paris in $1755(2,3)$. Her artistic skills were evident by her teenage years. Having developed a naturalistic style that was flattering to her subjects, Vigée Le Brun achieved early success as a fashionable portrait artist for an aristocratic clientele. Over a 7 -decade artistic career she created more than 660 portraits and 200 landscapes. She married, had a supportive husband who was also in the art world as a picture dealer, and became a mother.
Yet Vigée Le Brun lived in turbulent times. Her powerful and wealthy patron was Marie Antoinette, the queen of France, who was strikingly unpopular with the French people. Vigée Le Brun tried to soften and rehabilitate the queen's image with some 30 portraits. Many were maternity-themed paintings; the lovely, domestic Marie-Antoinette and her Children (Figure 1A), brought Vigée Le Brun to the peak of her career. But come the revolution, French royalty was forced from the throne and Marie Antoinette was publicly beheaded at the guillotine, along with tens of thousands of others. Being so closely associated with the royal family placed Vigée La Brun in a precarious position. She wisely left France for Italy and became a virtual nomad for twelve years, continuing to paint aristocratic portraits for nobles in countries untouched by revolution (4). She returned to France when the political climate stabilized.

Academic lives can be long. Scientists' careers and fates can ebb and flow as a result of their relationships with others - particularly if those patrons are influential (though few today are royalty, and fewer still wield the power [or suffer the fate] of Marie Antoinette). Extramural funding fluctuates along with politics and priorities of the funding agencies as well as contemporary health concerns of a population. It is important for scientists to recognize when times are changing and to be nimble in their response, to be bold in taking on new challenges while building on established skills and methodologies. Scientists also need to know when to leave their current location for one that promises greener pastures: more resources, richer collaborations, better infrastructure, or simply fewer obstacles. We should prepare our mentees to navigate the challenging times of a changing world.

Conflict of interest: The authors have declared that no conflict of interest exists.

Mary Cassatt (US, 1844-1926): Go where the action is!

Born in Allegheny City, Pennsylvania, in 1844, Mary Cassatt began her art training at the oldest art museum and school in the United States, the Pennsylvania Academy of Fine Arts in Philadelphia (5). Cassatt wanted more than the usual curriculum, which focused on copying works of art created by others. Unlike most female students in her class, she wanted to become a professional artist and to create her own works of art. She found her male colleagues patronizing and resentful of her presence and perceived her training at the academy to be slow-paced and conventional.

Cassatt was fortunate that her economic circumstances enabled her to go across the Atlantic in 1866 to study in France. At first she tried to enter an art academy, but found the community no more welcoming for female artists than in the US, so she undertook private instruction. Following the devastation of the Franco-Prussian War, she moved back to the US in 1870. Cassatt tried to establish a foothold in Chicago, only to see two of her paintings burn up in the Great Chicago Fire of 1871. She returned to Europe and eventually settled back in France in 1874 .

There she found a city aglow with the latest technology and infused with spectacular artistic innovations of the avant-garde artists associated with the Impressionist exhibitions $(6,7)$. Their focus on light, color, movement and, most importantly, human perception in visual arts challenged longstanding artistic conventions. With Degas, Manet, and Monet all in their prime, it was an exciting time to be in Paris. Clearly in "the right place at the right time," Cassatt took full advantage of the opportunity.

More than other painters of the time, Cassatt brought a conception of women's lives not as stereotypes, but as lived in every-day life (8). In her painting Mother Bathing a Baby in the Tub (Figure 1B) she art- 

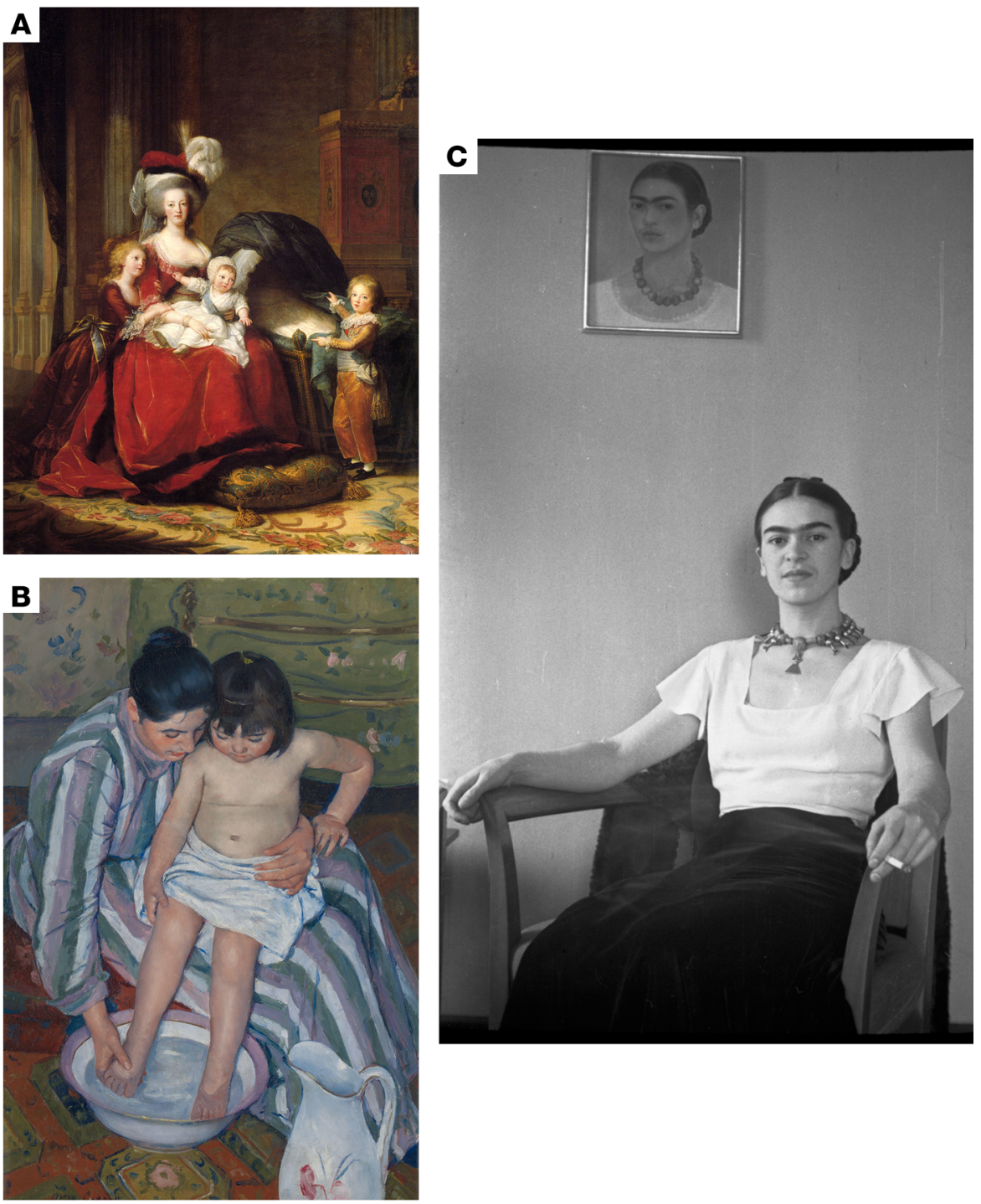

Figure 1. Iconic paintings by LaBrun, Cassatt, and Kahlo. (A) Marie-Antoinette and her Children by Elisabeth Vigée La Brun, (B) Mother Bathing a Baby in the Tub by Mary Cassatt, and (C) Frida at the Barbizon Hotel, photograph by Lucienne Bloch, features Self Portrait with Necklace by Frida Kahlo, painted with photographic precision. Photograph reprinted with permission, courtesy Old Stage Studios, New York City, NY.

fully captured a loving, but routine moment between a mother and her child. Nor did she remain static in her approach. She drew inspiration from diverse places such as Japanese art. Cassatt learned the use of pastels and copper engraving from Edgar Degas, whose pastels had inspired her when she first saw them on display on the Boulevard Haussmann (3). At his invitation, she exhibited at the fourth Impressionist exhibition of 1879, the only American officially associated with the group. Yet, she was unable to escape being labeled in terms of her gender. Even her mentor and supporter Degas observed that "No woman has a right to draw like that" (5).

\section{Frida Kahlo (Mexico, 1907-1954): Our imperfections make us complete}

Frida Kahlo was born in 1907 in Mexico City to Matilda and Guillermo Kahlo. Guillermo Kahlo was a photographer who specialized in portraits - a practice that served as an inspiration for Kahlo (9). From childhood, Kahlo was plagued by illness and injury. Poliomyelitis left her with leg length discrepancy as well as scoliosis requiring her to wear a corset (10). At age 18, she was seriously injured in a bus crash. A steel bar pierced her pelvis, injuring her spine, clavicle, and right leg in multiple places, and left her requiring over 30 surgeries. As a result, her dream to become a doctor never materialized. She turned instead to art, where her ill health, pain, sorrow, and disability took a center stage (11).

She married Diego Rivera, a renowned muralist, and soon thereafter had several miscarriages and abortions leaving innumerable emotional scars. With Rivera at the height of his artistic career, they moved to Detroit for a year in 1932 (9). This move away from her native country and family, although challenging, propelled Kahlo to create art that was more direct, honest, and self-assured. She often used her own life, health, and emotions as the basis of her work, famously stating "I paint self-portraits because I am so often left alone, because I am the person I know best." Later she confronted her pain and suffering in The Broken Column (1944). Standing in a desolate landscape, nails pierce her face and body, extending to her polio-affected right leg - the largest nail pierces her heart. She is wearing a brace for scoliosis and a broken Ionic column is running through her spine. Her precision in painting Self Portrait with Necklace (1933) and her direct gaze compels the viewer to confront reality and life (Figure 1C).

Kahlo's work at first was not taken seriously, especially in contrast with her more flamboyant husband. Indeed, one newspaper announced her arrival into the US with "Wife of the master mural painter gleefully dabbles in works of art" (12). Rivera, although a source of emotional pain to Kahlo due to his various extramarital affairs, knew better. He promoted the originality of his wife's work, noting that "Immediately thereafter [her abortion], she began work on a series of masterpieces which had no precedent in the history of art - painting which exalted the feminine qualities of truth, cruelty and suffering." Kahlo's legacy today looms large, and her art is considered every bit as consequential as Rivera's.

Kahlo's life and work teaches us to be honest and open about both our talents and our shortcomings. Her belief in herself, while living a life under the shadow of her larger-than-life husband and some not very subtle misogyny, may have parallels with scientists today working in pioneering laboratories. Often, academic structure compels us to conform. Kahlo teaches us that as we work within that system we need to make 
room for the disappointments and wounds that are inevitable. But as we find a way to mend ourselves, we should always persist in a way that is authentic to one's self.

\section{Conclusions}

Overcoming hardships, crossing boundaries, taking risks, and developing new relationships with innovative figures takes courage, but it can yield rewards if we can learn to see potential in unfamiliar places and untested methodologies. These three accomplished women artists can teach us the importance of enlisting and using all possible support available - including friends, family, mentors, and emerging institutional resources. They also teach us the importance of being able to move, both physically and stylistically.

During our careers as scientists it is easy to lose sight of the broader universe, of the many other people who, like us, have tried to create something new, original, useful, and - yes - beautiful. Women have faced, and continue to face, a harder path to success. By looking outside of the scientific world and to the world of art we can, in these three examples, learn that the obstacles that confront us are often not unique, and that we can perhaps learn from and build on the experiences of those who have come before us.

\section{Acknowledgments}

This paper was inspired in part by interactions made possible through the Medical Arts Program of the University of Michigan Medical School, a program dedicated to the idea that the arts have value for scientists and physicians.

Address correspondence to: Lona Mody, University of Michigan Medical School, Division of Geriatric and Palliative Care Medicine, 300 N. Ingalls Road, Room 905, Ann Arbor, Michigan 48109, USA. Phone: 734.764.8942;

Email:lonamody@umich.edu.

1. Osler W. Aequanimitas, With other Addresses to Medical Students, Nurses, and Practitioners of Medicine. Philadelphia, PA: Blakiston Company; 1932. 2. Baetjer K. Elisabeth Louise Vigee Le Brun (17551842). In Heilbrunn Timeline of Art History. New York: The Metropolitan Museum of Art. https:// www.metmuseum.org/toah/hd/vgee/hd vgee. htm. Updated May 2016. Accessed August 19, 2019.

3. Baillio J, Baetjer K, Lang P. Vigée Le Brun. New York, NY: Yale University Press; 2016.

4. Goodden A. Madame Vigće Le Brun, 1755-1842: the artist in exile. The Court Historian. 1997;2(2):34-38.

5. Barter JA, et al. Mary Cassatt, Modern Woman. Exhibition catalogue. Chicago, IL: Harry N. Abrams; 1998.

6. Roe S. The Private Lives of the Impressionists. New York, NY: Harper Perennial; 2007.

7. Samu M. Impressionism: Art and Modernity. In Heilbrunn Timeline of Art History. New York: The Metropolitan Museum of Art. http://www.metmuseum.org/toah/hd/ $\mathrm{imml} /$ hd_imml.htm. Updated October 2004. Accessed August 19, 2019.

8. Yeh SF. Mary Cassatt's images of women. Art Journal. 1976;35(4):359-363.

9. Rosenthal M. Diego Rivera and Frida Kahlo in Detroit. Detroit, MI: Detroit Institute of Arts; 2015.

10. Jamison L. Frida's corsets. The Paris Review. https://www.theparisreview.org/ blog/2011/08/22/frida's-corsets/. Published August 22, 2011. Accessed August 19, 2019.

11. Lomas D, Howell R. Medical imagery in the art of Frida Kahlo. BMJ. 1989;299(6715):1584-1587.

12. Davies F. Wife of the master mural painter gleefully dabbles in works of art. Detroit News. Detroit, MI, USA: 1933 